Siaska I. O. Structural components, criteria and levels of compatibility of the ecological competency of future teachers of natural sciences

The article considers the main approaches of native educationists to the determintion of the structure of ecological competency of future specialists. The factors that influence on the selection of the components of the ecological competency of future teachers of natural sciences are analyzed. The structure of the mentioned personality formation is substantiated and its components are determined: information-cognitive, value-motivational, professional-activity, reflexive-estimable. The content of the information-cognitive component is determined by the level of formation of students' ecological thinking, the assimilation of the system of environmental knowledge and the ability to apply this knowledge in the processes of environmentally appropriate everyday and professional activities. Value-motivational component is manifested through the attitude to nature as an indisputable value, involves awareness of itself as part of nature and the need to apply socio-economic constraints and correction of their own needs. The professional-activity component is characterized by the degree of personality acquisition by the ecological content of everyday and professional activity, the indicators of which are the ability to practically apply the acquired knowledge, skills, value orientations, experience of ecological activity in during the adoption of environmental decisions in professional and life situations. The ability to correct its own behavior and activities in the environment, to predict its consequences and to bear responsibility for it on the basis of self-reflection, self-regulation and development of ecological self-awareness is manifested in the formation of reflexive-estimable component of ecological competency. The criteria of diagnostics and the level of formation of the ecological competency of the individual are determined.

Key words: ecological competency, teacher of natural sciences, institution of higher education, structure of ecological competency.

\author{
УДК 378.147-057.36
}

DOI https://doi.org/10.31392/2311-5491/2019-69.59

Taimasov Yu. S., Zub O. V., Turchynov A. V.

\title{
ANALYSIS OF APPROACHES TO THE "INDIVIDUAL SELF-SAVING" CONCEPT IN PSYCHOLOGICAL AND PEDAGOGICAL LITERATURE
}

The article presents the results of the analysis of approaches to individual self-saving. It is emphasized that in analyzing the selfsaving phenomenon it is necessary to understand how the term directly explains this phenomenon means. The study of reference literature in this direction has shown that this notion has no clear definition. This is a general term that denotes behaviour models aimed at increasing the chances of survival. A number of sources call it the desire to save their lives or attained a standard of living and activity, "fasten" at the "heights" taken. Some scientists associate it with the health of the individual, others, touching one way or another on this issue, generally, avoid a specific definition of self-preservation of the individual. Based on analyzed literary sources, it has been emphasized that self-saving is based on the corresponding instinct and is manifested in behaviour, which is called self-saving. Self-saving personality behaviour acts as an integral part of a complex socio-demographic aggregate, which includes a society that regulates its social institutions of marriage and family; the economic, political, and ecological state in the country, which affects the birth of children and their health; the cultural level of personality, on which depends the level of development of the future member of society and its place in it, etc. Despite the fact that these factors operate in close connection with each other, we can distinguish the following among them: psychological (the unrepeatable combination of personal characteristics, temperament, the strength of emotional-volitional characteristics of each individual, including those that are directly connected with self-saving); biological (the natural desire to preserve its organism, which is based on instincts and is provided by certain uncontrolled consciousness functions of the organism); socio-demographic (the ability of society to influence the life of each member, depending on their level of development, and the desire to create a family and leave the descendants to continue the existence of society); intellectual-applied (knowledge and skills of the individual on self-saving, experience of their use); medical (human qualities, directly related to the care of their own health and carrying out actions for its restoration); economic (level of financial support, which affects the possibility of taking certain measures for self-saving and providing appropriate living conditions); ecological (the environment condition, on which individual's life expectancy and health level depend on); moral (cultural, religious, value aspects of human life that are connected with categories of life and death).

Key words: self-saving, individual, analysis, approach, source, concept, health, model.

(статтю подано мовою орихіналу)

At the present stage of development of scientific thought, the phenomenon of readiness has its development mainly in the area of studying psychological, pedagogical and acmeological features in the following areas: readiness for activities in extreme conditions (O. Barabanshchikov, V. Varvarov, V. Plisko) ; professional readiness (S. Zanyuk, V. Krutetskii, S. Kubitsky, A. Makarevich, A. Markov, L. Nersesyan, I. Okulenko, B. Smirnov). Obviously, readiness for self-saving is necessary to the rescuer during all time of his service, which is connected with extreme conditions of professional activity, therefore, it interests us as a personal formation. Note that the analyzed literature clearly shows the existence of the age criterion of research areas, the separate significant branches of which are the study of the readiness of junior school age children $(\mathrm{N}$. Cherepanya), senior school age boys and girls (A. Balitskaya, P. Gornostay, V. Dorokhin, I. Kon) and students (L. Kondrashov, S. Koryshenko, A. Linenko, V. Molyako).

In our opinion, in analyzing the phenomenon of self-saving it is necessary to understand how the term directly explains this phenomenon means. The study of reference literature in this direction has shown that this notion has 
no clear definition. So, according to the Oxford Psychology Dictionary, this is a general term that denotes behaviour models that are aimed at increasing the chances of survival. A number of sources call it the desire to save their lives or attained the standard of living and activity, "fix" at the "heights" taken. Some scientists associate it with the health of the individual [6], others, generally avoid the specific definition of self-saving [4].

The researcher $\mathrm{O}$. Vygovskaya interprets self-saving through the prism of human self-realization as a characteristic that reflects the meaning of life for it itself. The scientist, creating a conceptual model of constructive self-saving of a person, includes its signs of the adequacy of its behaviour, preservation, and strengthening of her personal health. These components, according to the author, determine the readiness to ensure human security [3, p. 97]. Separately, we will note the research of G. Bakulin, M. Beloy and V. Tsvetkov, devoted to the problem of the effectiveness of the training of ships crews to fight for survivability, among the existing forms of which the authors as a priority distinguish security, the provision of which is directly related to life and health of the person. Considering the conceptual vagueness, as well as the general and semantic information available, we have drawn attention to the fact that this concept is used along with the corresponding instinct. This position was widely reflected in the scientific literature. We are impressed by this point of view because it does not outlive the biological aspect of self-saving, which plays a significant role.

According to their teachings, one of the fundamental foundations of the whole complex of self-saving is the desire of the human body to preserve itself as a biological object. This is known for a long time since it was formed from the first generations of living beings and is based mainly on instincts.

I. Mechnikov calls self-saving "the instinct of life". The scientist emphasizes that this phenomenon is reflected in all living beings (despite the level of their biological development, on which depends only complexity and multi-levelness of the self-saving process). Thus, plants and lower animals have adaptations that provide them with protection from enemies in the absence of any mental acts, which began to appear later in the form of numerous instincts. However, people's instinct for self-saving depends on age. Thus, its development is largely synchronized with the development of the individual: almost absent at birth, more pronounced in young children and is unstable in young people (the consequence of this nature is their propensity to the risk and careless actions), reminding themselves of life-threatening situations and their health. Such reflections lead the scientist to the idea that with age the person begins to appreciate life, so the instinct of self-saving gains strength over the years.

Based on the analyzed literary sources, we believe that self-saving is based on the corresponding instinct and is manifested in behaviour, which is called self-saving.

As already mentioned, self-saving behaviour was investigated by A. Antonov from the perspective of life expectancy, the regularities of human existence in the ordinary society, families that significantly differ from the conditions of education and the formation of the personality of a future specialist in higher educational institutions.

Thus, self-saving personality behaviour acts as an integral part of a complex socio-demographic aggregate, which includes a society that regulates its social institutions of marriage and family; the economic, political, and ecological state in the country, which affects the birth of children and their health; the cultural level of personality, on which depends the level of development of the future member of society and its place in it, etc. According to the demographic dictionary, self-saving behaviour is targeted action to preserve and strengthen health. It is noted that "a way of life that promotes health" should be actualized not only in deliberately made decisions but also to be a realistic and attractive alternative to everyday people stereotypes [5]. As we can see, the higher effectiveness of the voluntary education of self-saving behaviour, based on the sincere desire of the individual to self-saving, is compared with non-alternate implanting of such a form of life. V. Borisov calls self-saving behaviour similarly to reproductive; a system of actions and personality adjustments, aimed at maintaining health and the continuation of life [1].

Thus, these researchers recognize the tendency to increase the importance of self-saving personal behaviour in modern society. The reasons for this are obvious: the gradual technological development of humanity has led to the emergence of new and exacerbated old threats to humans; the emergence of dangerous occupations; the complication of the socio-cultural state of society, which leads to increasing in the number of crimes and suicides, exacerbation of environmental problems, resulting in deterioration of the general health people, etc.

The analysis made it possible to determine the main factors in the formation of individual self-saving behaviour. Under this we understand the peculiarities of life which are capable of exerting a positive or negative influence, thus stipulating its specificity for each person.

Despite the fact that these factors operate in close connection with each other, we can distinguish the following among them:

- psychological (the unrepeatable combination of personal traits of character, temperament, the strength of emotional-volitional characteristics of each person, including those directly related to self-preservation);

- biological (the natural desire to preserve organism, which is based on instincts and is provided by certain consciousness functions of the organism);

- socio-demographic (the ability of society to influence the life of each person, depending on their level of development, and the desire to create a family and leave the descendants to continue the existence of society);

- intellectual-applied (knowledge and skills of the individual on self-preservation, the experience of their use);

- medical (human qualities, directly related to the care of their own health and carrying out actions for its restoration); 
- economic (level of financial support, which affects the possibility of taking certain measures for self-saving and providing appropriate living conditions);

- ecological (the state of the environment, on which life expectancy and health level depend on);

- moral (cultural, religious, value aspects of human life that are connected with life and death categories).

In our opinion, this is a reflection of the stereotype which dominated the public consciousness: a person should not be conceived to sacrifice himself in the name of another person - and has created a common view that such behaviour is natural for him. This conviction has become a consequence of the generally accepted "equation": an additional danger to human life should increase the chances of victims to be safe for their lives and health. At first sight, everything is logical: the less an individual will be distracted by the numerous obstacles and dangers on the way to another individual, (respectively, risking more and more) the sooner he will be able to be close to him and to provide assistance. However, a more detailed review of this statement suggests that it does not withstand any criticism and is not productive in terms of both biology and psychology. We can not forget that the success of all work depends on the complex of physical training and moral stability. Separately, these qualities will not give a sufficient effect. Hence, the probability of failure is increasing. While such an insignificant probability remains, we have to talk about the problem. Because the result of activity in this profession is measured by the highest social value-human life.

To understand the processes of occurrence and resolution of psychological conflicts we turn to the position of the famous German psychoanalyst S. Freud, who devoted the subject of conflicts and their consequences to a huge amount of his research. It is known that the Freud divided psyche of human into three levels: consciousness, subconscious, and the unconscious. Moreover, in his opinion consciousness includes only a small part of the mental human life, the tip of the iceberg. An unidentified scientist considered that there is a huge repository of instinctive motives and emotions, which is crucial in the daily functioning of the human psyche. Determining its foundation, S. Freud concludes that much of the components of human behaviour are sent by impulses and reflexes. He noticed that not only the acts but also the causes are inaccessible to our consciousness and occur without its participation. It is logical to assume that inducing people to endanger their lives is contrary to their natural behaviour and harming for mental health. L. Hell wrote that S. Freud dived into his research even further and showed an interesting relationship. As soon as the influence of instincts becomes conscious, it encounters strong internal resistance [7]. Accordingly, the elements of self-saving begin to manifest so clearly that a person will pay attention to him. This will cause internal discomfort, despite the fact that these elements are laid in his subconscious, and he can not influence them. Self-saving behaviour can disassociate this state (which threatens to grow into another psychic conflict). More precisely, the competent conduct of the process of its growth. It is important that it has found its niche and at the conscious level of the individual. Thus, a person will be in relatively comfortable psychological conditions: he will understand that his duties are in harmony with instinctive needs, and their manifestations will not create any inconvenience for him. Thus, our goal is achieved in relation to the cultivation of self-saving behaviour: in the fact that it is virtually impossible to exclude all the difficulties and dangers that affect a person from the outside. It is especially important to create the most favorable conditions, that is, the above-mentioned complex. One of the most important steps towards recognizing the importance of preserving human life and health has been the change in the official position regarding their actions during the performance of their duties, as reflected in the normative documents. We want to emphasize the word "justified" because we consider it crucially important to introduce the notion of "justified risk" since the small difference in the wording is of great significance. We should pay attention to the normalization of work participants safety. Thus, now the responsibility of the head is not to encourage subordinates to take risks but to ensure that the need for risk was unequivocally reasoned and reasonable. That is a vital necessity. Let's dwell on the concept of "justifiable risk" more detailed. Under "justifiable risk" we should understand the choice of such action or decision, the process of implementation of which will not exceed the permissible level of negative consequences for the moral, psychological, physical state of people [2]. We believe that, in general terms, this is the main mission of a person for the realization of which he is obliged to possess advanced self-saving behaviour. Obviously, the attitude to risk has changed dramatically: if before it was a norm and a practical obligation, now it is the avoidance of thoughtless actions and decisions. This is a confirmation of the fact that preserving the person's life and health of the is one of the priority goals of carrying out operations on the elimination of the consequences of accidents, afflictions and natural disasters. In turn, it makes self-saving behaviour a cornerstone of this profession representatives readiness. As we see, self-saving has nothing common with responsibility self-exclusion. Speaking about the self-sustaining behaviour, we mean not the desire to preserve life and health at the expense of the professional duties performance.

Conclusions. In conclusion, we note that the development of a combination of conscious self-saving behaviour with traditional measures can create a model of a more prepared individual. They emphasize the exceptional importance and humanity of the people's saving mission. Obviously, in contrast to all sorts of psychological problems and stress, a person gets a sense of balance between realizing the value of his own life and the value of the victim's life. This absolutely does not contribute to the fulfillment of professional duties. Consequently, the formation of individual self-saving behaviour should take into account age development of their mental qualities and development of consciousness. At this stage of life, it already has the established patterns, the process of changing which is associated with certain difficulties. Thus, the concept of self-saving is the result of self-sustaining behaviour 
implementation. It is based on the instinct of self-saving and is a process of interaction with the environment and its purpose is to preserve life and health.

\section{Bibliography:}

1. Борисов В. А. Демография. Москва : Издательский дом "NOTA BENE”, 2001. 272 с.

2. Вдовиченко О. В. Минимизация неоправданного риска. Наука і освіта. Одесса, 2009. № 5. С. 32-38 / Национальная библиотека Украины имени В. И. Вернадского. URL: http://archive.nbuv.gov.ua/portal/soc_gum/NiO/2009_5/1_razdel/ vdovigh.htm

3. Віговська О. О. Самореалізація як ознака конструктивного самозбереження особистості. Проблеми сучасної психології. Кам'янець-Подільський, 2014. Вип. 23. С. 90-99.

4. Габриелян К. Г. Ермолаев Б. В. “Культура самосохранения” в высшей школе. Высшее образование в России. Москва : МГУП им. Ивана Федорова, 2005. № 6. С. 111-115.

5. Демографический понятийный словарь / под редакцией Л. Л. Рыбаковского. Москва : Центр социального прогнозирования, 2003. 352 с.

6. Зайцева Е. Г. Проблема самосохранения жизни и здоровья работников. Вестник Научного иентра по безопасности работ в угольной промышленности. Кемерово : ООО “ВостЭко”, 2008. № 1. С. 74-79.

7. Хьелл Л. А., Зиглер Д. Дж. Теории личности: Основные положения, исследования и применение ; перевод с английского С. Меленевская, Д. Викторова. Санкт-Петербург : Питер Пресс, 2003. 608 с.

\section{References:}

1. Borisov V. A. Demography / V. A. Borisov // M .: Publishing house NOTA BENE, 2001. 272 p.

2. Vdovichenko O. V. Minimizing unnecessary risk [Electronic resource] / O.V. Vdovichenko // Science and Education. - Odessa, 2009. - No. 5. - P. 32-38 // National Library of Ukraine named after V.I. Vernadsky - Access mode: URL: http://archive.nbuv.gov. ua/portal/soc_gum/NiO/2009 5/1_razdel/vdovigh.htm

3. Vygovskaya O. O. Self-realization as a sign of constructive personality self-saving/ O. O. Vygovsky // Problems of modern psychology. - KamianetsPodilsky, 2014. Vip. 23. P. 90-99.

4. Gabrielyan K. G. "Self-saving culture" in high school / K. G. Gabrielyan, B.V. Ermolaev // Higher education in Russia. - Moscow: Moscow State University named after Ivan Fedorov, 2005. - No. 6. - P. 111-115.

5. Demographic Conceptual Dictionary / [edited by L. L. Rybakovskii]. - M.: Center for Social Forecasting, 2003. - 352 P.

6. Zaitseva E. G. The problem of workers' life and health self-saving / E.G. Zaitseva // The Bulletin of the Scientific Center for Safety of Works in the Coal Industry. - Kemerovo: OOO VostEko, 2008. - No. 1. - P. 74-79.

7. Hjell L. A. Theories of Personality: Basic Situations, Research, and Application / L. A. Hjell , D. J. Ziegler; translation from English S. Melenevskaya, D. Victorova. - St. Petersburg: Peter Press, 2003. - 608 P.

Таймасов Ю. С., Зуб О. В., Турчинов А. В. Аналіз підходів до поняття «самозбереження індивіда» у психолого-педагогічній літературі

У статті представлені результати аналізу підходів до самозбереження індивіда. Наголошено, щзо під час аналізу феномена самозбереження необхідо зрозуміти, що означає термін, котрий безпосередньо пояснює це явище. Дослідження довідкової літератури в цьому напрямі показало, щцо зазначене поняття не має чіткого визначення, ие загальний термін, який позначає моделі поведінки, направлені на збільшення шансів виживання організму, низка джерел називає його прагненням зберегти своє життя або досягнутий рівень життя та діяльності, “закріпитися” на взятих “висотах”, деякі науковиі пов'язують його зі здоров'ям індивіда, інші, торкаючись тим чи іншим чином даної проблематики, взагалі уникають конкретного визначення самозбереження індивіда. Спираючись на проаналізовані літературні джерела, наголошено, щчо самозбереження засновується на відповідному інстинкті та виявляється в поведіниі, яку називають самозберігаючою. Самозберігаюча поведінка особистості виступає складовою частиною складного соиіально-демографічного комплексу, щчо включає в себе суспільство, яке регулює його соичальними інститутами шлюбу та сім'ї, економічний, політичний, екологічний стан у державі, котрий впливає на народження дітей та рівень їх здоров'я, культурний рівень особистості, від якого залежить рівень розвитку майбутнього члена суспільства та його місие у ньому тощцо. Незважаючи на те, щцо ичі фактори функціонують у тісному зв'язку один з одним, серед них можна виділити такі: психологічні (неповторюване поєднання особистих рис характеру, темперамент, силу емочійно-вольових характеристик кожного індивіда; в тому числі й тих, щуо безпосередньо стосуються самозбереження); біологічні (природнє прагнення зберегти свій організм, яке засновується на інстинктах та забезпечується певними непідвладними свідомості функиіями організму); соціально-демографічні (здатність суспільства залежсно від рівня свого розвитку впливати на життя кожного свого члену та бажання створити сім'ю $i$ залишити нащадків, щзоб продовжити існування суспільства); інтелектуально-прикладні (знання та навички індивіда по самозбереженню, досвід їх використання); медичні (якості людини, безпосередньо пов'язані з піклуванням про рівень власного здоров'я та проведення дій щчодо його відновлення); економічні (рівень фінансового забезпечення, який впливає на можливість вживати певних заходів по самозбереженню та забезпечувати відповідні умови життя); екологічні (стан навколишнього середовища, від якого залежить тривалість життя та рівень здоров'я індивіда); моральні (культурні, релігійні, иіннісні аспекти життя людини, щзо так чи інакше пов'язані з категоріями життя та смерті).

Ключові слова: самозбереження, індивід, аналіз, підхід, джерело, поняття, здоров'я, модель. 